REVIEW ARTICLE

\title{
Clinical pharmacology in the last decade
}

\author{
PAul TURner \\ M.D., B.Sc, F.R.C.P.
}

Department of Clinical Pharmacology, St Bartholomew's Hospital, London ECIA 7BE

\section{Introduction}

Clinical pharmacology in the United Kingdom can be said to have come of age in the 1970s. Most teaching hospitals have departments of clinical pharmacology, and several universities have separated it from medicine in the final graduating examination so that medical students have to pass in clinical pharmacology in order to graduate. It is a recognized clinical speciality within the National Health Service, and the Joint Committee for Higher Medical Training of the Royal College of Physicians has a Specialist Advisory Committee in Clinical Pharmacology which has laid down a programme of higher training in the subject comparable to training programmes in other medical specialities and has approved posts in particular departments for such training. An encouraging number of physicians have already been accredited in clinical pharmacology after going through this training programme. A critical development in the subject has been the recognition that clinical pharmacology has an important role in general medicine and patient care, not only in the teaching hospital (Wood, Turner and Vere, 1980), but also in district general hospitals (Editorial, 1978), and several appointments have been made to such hospitals of general physicians with an interest in clinical pharmacology. It is hoped that these appointments will demonstrate the value of the speciality in the NHS regions and districts and that more will be made within the next decade. Trainees in clinical pharmacology are not limited to such posts, however, and many physicians who have spent several years in departments of clinical pharmacology are now in consultant posts in other specialities such as gastroenterology, cardiology, chest medicine, neurology and rheumatology, to which they are able to bring the experience of a scientific training in drug evaluation and use.

\section{Pharmacokinetics}

Pharmacokinetics, the study of drug disposition within the body and the factors that influence it, began to dominate the pharmacological scene in the 1960 s, so much so that some graduates in the pharmaceutical sciences came to believe that an accurate measurement of the plasma level of a drug or its metabolite would be a more accurate measure of a drug's action than a pharmacological or therapeutic response to the drug. During the past decade, however, the role and limitations of pharmacokinetics have been put into perspective. Some of the factors that govern the relationship between drug concentration and pharmacological response have been defined (Turner, 1978a) and the place of pharmacokinetics in therapeutics clarified (Dollery, 1973). An important factor that has contributed towards this change of emphasis has been the development of acceptable and safe methodology, much of it non-invasive, to measure drug responses in man (e.g. Shanks, 1979).

During the past decade the concept of 'individualization' of drug dosage has received considerable emphasis (Koch-Weser, 1975), and therapeutic drug monitoring is an integral part of this in the use of phenytoin, quinidine, theophylline, lithium and aminoglycoside antibiotics. Routine monitoring may also be justified in some patients receiving other anticonvulsant and antidysrhythmic drugs and, possibly, some monoamine re-uptake inhibiting ('tricyclic') antidepressant drugs (Richens and Warrington, 1979). An important limitation to this, however, is the problem of considerable inter- and intra-laboratory variation in quality of accuracy of drug analysis, and quality control schemes have, therefore, been set up in an attempt to reduce this variability and improve the standard of patient care (Richens, 1978).

Improved and more sophisticated methods for estimation of drugs and their metabolites have permitted an increase over the last decade in our understanding of factors influencing drug distribution in the body, including blood flow, clearance, plasma and tissue binding, and route of administration (Shand, 1978).

\section{Important pharmacological developments with immediate clinical implications \\ Receptor activity and blockade in man}

During the past decade, considerable progress has been made in our understanding of the role of 
receptor agonism and antagonism for a variety of transmitter substances.

The classifications of adrenoceptors by Ahlquist (1948) and Lands et al. (1967) was extended by the realization of the importance of pre- as well as postsynaptic receptors which modulate transmitter release (Langer, 1977). This, together with the demonstration of central nervous adrenoceptors concerned with the control of sympathetic outflow, has made possible a better understanding of the mechanisms of action of some antihypertensive drugs such as clonidine and methyldopa (Davies and Reid, 1976). The mechanism of the antihypertensive action of $\beta$-adrenoceptor blocking drugs is still not clear, although a variety have been suggested (Turner, $1978 \mathrm{~b})$. It is unlikely that a central mechanism is important in this action, although the central effect of $\beta$-blocking drugs has attracted much interest, not only because of their therapeutic actions in tremor, anxiety and migraine, but also because of claims for an antipsychotic effect (Turner, 1979). This may well be unrelated to $\beta$-adrenoceptor blockade, however, because they have been shown, in addition, to possess potent binding properties to 5-hydroxytryptamine receptors, which may contribute to their central actions.

Dopamine receptors have attracted considerable clinical interest because of their importance in psychiatric, neurological, endocrine and peripheral vascular function. There is much evidence suggestive of a role in the antiemetic and antipsychotic actions of phenothiazine and similar drugs, and their importance in Parkinson's disease has been demonstrated by the therapeutic effect of the direct dopamine receptor agonist drug bromocriptine in this condition (Parkes, Debono and Marsden, 1976). The potent prolactin-secretion inhibiting effect of bromocriptine has also permitted further elucidation of the role of dopamine in controlling prolactin release (Mashiter et al., 1977). Dopamine has also attracted much interest through its actions on the heart and peripheral vasculature, particularly its dilator effects in the renal arterial system (Goldberg and Weder, 1980).

A major advance in the past decade has been the introduction of a histamine 2-receptor blocking drug, cimetidine, for clinical use. Its place in the management of peptic ulcer and other gastrointestinal conditions is still being assessed, but it has already permitted some evaluation of the role of $\mathrm{H}_{2}$ receptors in other systems, including the central nervous and cardiovascular systems (Langman, 1980).

Autoradiographic studies using isotopicallylabelled selective receptor-blocking drugs have permitted quantitation of receptor numbers in tissues. These have shown, not only that a reduction in transmitter availability is associated with an increase or 'up-regulation' in receptor number, an an increase in transmitter with a decrease or 'down? regulation' in receptor population, but that age, other drugs, endogenous substances, and certai $\overrightarrow{\overline{\vec{m}}}$ disease states may also change receptor numbers (Davies and Lefkowitz, 1980; Turner, 1980). These observations have received further support fron studies of cellular cyclic AMP concentrations an their response to stimulation with receptor agonists such as isoprenaline, in which changes have beefp shown to be consistent with the findings of recepto $\vec{D}$ binding studies (Greenacre and Conolly, 1978 Greenacre, Schofield and Conolly, 1978).

\section{Prostaglandins and prostacyclin}

The importance of the prostaglandin, thromboxan and prostacyclin derivatives of arachidonic acid in physiology and in many different pathological states is now well known, and has been the subject of many reviews. Bennett (1978) has reviewed the evidences for their involvement in atherosclerosis and othep forms of peripheral vascular disease, metastatic. spread of breast cancer, hypercalcaemia, patency of ductus arteriosus, gastro-oesophageal reflux, druge induced gastric bleeding, diarrhoea from radiation and endotoxins, and Bartter's syndrome, as welbast the exciting hypothesis that some non-sterowat anti-inflammatory drugs such as aspirin and indomethacin act by inhibiting prostaglandin synthesis

The discovery of prostacyclin $\left(\mathrm{PGI}_{2}\right)$ has fundas mentally altered our understanding of thrombosi and haemostasis (O'Grady, 1980), and there is already some exciting evidence that it may be involved in toxaemia of pregnancy (Lewis et al $\vec{\oplus}$ 1980) and in systemic sclerosis (Kirby et al., 1980) $\rightrightarrows$

\section{Peptide transmitters in the central nervous system}

Although the peptide substance $\mathbf{P}$ was discovered in the brain and other tissues by Von Euler and Gaddum in 1931, the importance of peptides as putative neurotransmitters has only really emergeg during the past decade, so that Snyder (1980) has now listed more than 20 and even thinks there may be more than 200 . Radioimmunoassay and immuno cytochemical techniques have shown that some peptides first identified in the gut wall, such as vasoactive intestinal polypeptide (VIP) and choles cystokinin are also found in the brain. Releasing and release-inhibiting factors first identified in the hypothalamus, such as thyrotrophin releasing hormone (TRH) and somatostatin have been foun to have wider central nervous distribution (Swees 1980; Editorial, 1980). Limited human studies an $\bar{\Phi}$ much animal evidence suggest that these peptides have roles in the control of behaviour, emotions sex and sleep. Vasopressin appears to have somet potential to stimulate memory in some patients wit 
dementia, and it may be involved in the therapeutic action of lithium in affective disorders (Gold, Goodwin and Reus, 1978).

Perhaps the most exciting of the peptide neurotransmitters to be discovered in the 1970s are the enkephalins and endorphins. It had been known for some years that the brain contained receptors which had a high capacity to bind morphine and other narcotics stereospecifically, and the development of synthetic selective partial agonists and antagonists, such as nalorphine and naloxone was further evidence for the presence of specific receptors for the narcotics. Pharmacologists had, therefore, sought for the brain's own endogenous ligand for which these receptors had evolved, and it was the Aberdeen group under Kosterlitz and Hughes who first identified the 2 similar pentapeptides metand leu-enkephalin, and showed that met-enkephalin had the same amino acid sequence of a larger peptide, $\beta$-endorphin (Tregear and Coghlan, 1980). The enkephalins are rapidly degraded by peptidases and therefore analogues which have longer activity have been studied in man, but so far their adverse effects have predominated over any potential therapeutic activity (Sweet, 1980). The relationship of $\beta$ endorphin to pain relief in man has been demonstrated by its increase in human third ventricular cerebrospinal fluid after electrical stimulation in the thalamus that produced marked or complete relief of severe pain (Sweet, 1980), and after acupuncture (Clement-Jones et al., 1980; Anzhong et al., 1980).

Enkephalins and endorphins do not appear to be limited in their pharmacological actions to an involvement in pain relief, however. There is contradictory evidence which suggests an involvement in schizophrenia, and they have also been claimed to have a role in regulating secretion of some pituitary hormones, thermoregulation, eating, learning, sexual behaviour and the regulation of central cardiovascular control and respiration (Tregear and Coghlan, 1980). There is evidence that they may be involved in the flushing that occurs in some chlorpropamide-treated subjects after consuming alcohol (Leslie, Pyke and Stubbs, 1979). It is tempting to see a relationship between their possible role in the chlorpropamide-alcohol syndrome in diabetics and the effect of morphine on blood glucose levels (Feldberg and Smyth, 1977).

\section{References}

AhLQUisT, R.P. (1948) A study of the adrenotropic receptors. American Journal of Physiology, 153, 586.

AnZhong, Z., Xiaoping, P., Shaofen, X., Jieshi, C. \& W ANYING, M. (1980) Endorphins and acupunture analgesia. Chinese Medical Journal, 93, 673.

Bennett, A. (1978) Prostaglandins. In: Recent Advances in Clinical Pharmacology, Vol. 1 (Ed by Turner, P. \& Shand, D.G.). Churchill Livingstone, Edinburgh.
Clement-Jones, V., Mcloughlin, L., Tomlin, S., Besser, G.M., ReES, L.H. \& WEN, H.L. (1980) Increased $\beta$-endorphin but not metenkephalin levels in human cerebrospinal fluid after acupuncture for recurrent pain. Lancet, ii, 946.

Davies, A.O. \& Lefkowitz, R.J. (1980) Adrenergic receptor regulation. In: Recent Advances in Clinical Pharmacology Vol. 2 (Ed by Turner, P. \& Shand, D.G.). Churchill Livingstone, Edinburgh.

Davies, D.A. \& ReID, J.L. (1976) Central Action of Drugs in Blood Pressure Regulation. Pitman Medical, Tunbridge Wells.

Dollery, C.T. (1973) Pharmacokinetics-master or servant? European Journal of Clinical Pharmacology, 6, 1 .

Editorial (1978) The role of the clinical pharmacologist in district general hospitals. British Journal of Clinical Pharmacology, 5, 3.

EdITORIAL (1980) Brain peptides-new synaptic messengers? Lancet, ii, 895.

FeldberG, W. \& Smyth, D.G. (1977) C-fragment of lipotrophin-an endogenous analgesic peptide. British Journal of Pharmacology, 60, 445.

Gold, P.W., Goodwin, F. K. \& Reus, V.I. (1978) Vasopressin in affective illness. Lancet, $\mathbf{i}, 1233$.

GoldberG, L.I. \& Weder, A.B. (1980) Connections between endogenous dopamine receptors and sodium excretion. In: Recent Advances in Clinical Pharmacology, Vol 2 (Ed by Turner, P. \& Shand, D.G.). Churchill Livingstone, Edinburgh.

Greenacre, J.K. \& Conolly, M.E. (1978) Desensitisation of the $\beta$-adrenoceptor of lymphocytes from normal subjects and patients with phaeochromocytoma. British Journal of Clinical Pharmacology, 5, 191.

Greenacre, J.K., Schofield, P. \& Conolly, M.E. (1978) Desensitisation of the $\beta$-adrenoceptor of lymphocytes from normal subjects and asthmatic patients in vitro. British Journal of Clinical Pharmacology, 5, 199.

Kirby, J.D.T., Lima, D.R.A., Dowd, P.M., Kilfeather, S. \& Turner, P. (1980) Prostacyclin increases cyclic-nucleotide responsiveness of lymphocytes from patients with systemic sclerosis. Lancet, ii, 453.

KOCH-Weser, J. (1975) The serum level approach to individualisation of drug dosage. European Journal of Clinical Pharmacology, 9, 1.

Lands, A.M., Arnold, A., McAuliff, J.P., Luduena, F.P. \& BROWN, T.G. (1976) Differentiation of receptor systems activated by sympathomimetic amines. Nature, 214, 597.

Langer, S.Z. (1977) Presynaptic receptors and their role in the regulation of transmitter release. British Journal of Pharmacology, 60, 481.

Langman, M.J.S. (1980) Histamine $\mathrm{H}_{2}$ antagonists. In: Recent Advances in Clinical Pharmacology, Vol. 2 (Ed by Turner, P. \& Shand, D.G.). Churchill Livingstone. Edinburgh.

Leslie, R.D.G., Pyke, D.A. \& Stubbs, W.A. (1979) Sensitivity to enkephalin as a cause of non-insulin dependent diabetes. Lancet, i, 341.

Lewis, P.J., Boylan, P., Friedman, L.A., Hensby, C.N. \& Downing, I. (1980) Prostacyclin in pregnancy. British Medical Journal, 280, 1581.

Mashiter, K., Adams, E., Bread, M. \& Holley, A. (1977) Bromocriptine inhibits prolactin and growth-hormone release by human pituitary tumours in culture. Lancet, ii, 197.

O'Grady, J. (1980) Prostacyclin. In: Recent Advances in Clinical Pharmacology, Vol. 2 (Ed by Turner, P. \& Shand, D.G.). Churchill Livingstone. Edinburgh.

Parkes, J.D., Debono, A.G. \& Marsden, D.D. (1976) Bromocriptine in Parkinsonism. Journal of Neurology, Neurosurgery and Psychiatry, 39, 1101.

Richens, A. (1978) Drug level monitoring-quantity and quality. British Journal of Clinical Pharmacology, 5, 285. 
Richens, A. \& WARRINGTON, S. (1979) When should plasma drug levels be monitored? Drugs, 17, 488.

SHAND, D.G. (1978) Recent advances in pharmacokinetics. In: Recent Advances in Clinical Pharmacology, Vol. 1 (Ed by Turner, P. \& Shand, D.G.). Churchill Livingstone, Edinburgh.

Shanks, R.G. (1979) Methods in Clinical PharmacologyCardiovascular System. Macmillan Journals, London.

SNYDER, S.H. (1980) Brain peptides as neurotransmitters. Science, 209, 976.

SWEET, W.H. (1980) Neuropeptides and monoaminergic neurotransmitters; their relation to pain, Journal of the Royal Society of Medicine, 73, 482.

Tregear, G.W. \& CoghlaN, J.P. (1980) En!sphalin and endorphin. In: Advances in Human Psychopharmacology, Vol. 1 (Ed by Burrows, G.D. \& Werry, J.S.). Jai Press, Connecticut.
TURNER, P. (1978a) Some aspects of the relationship betwe plasma drug levels and their pharmacological effects. I\$: Recent Advances in Clinical Pharmacology, Vol. 1 (Ed Ey Turner, P. \& Shand, D.G.). Churchill Livingstoné, Edinburgh.

TURner, P. (1978b) Beta-adrenoceptor blocking drugs $\underset{\text { in }}{ }$ hypertension. Clinical and Investigative Medicine, 1, $12 \%$

TURNER, P. (1979) Central nervous actions of beta-adren⿳亠二口犬ceptor blocking drugs in man. Trends in Pharmacologic Sciences, 1, 49.

TURNER, P. (1980) Some clinical implications of the recept(8) concept. Circulation Research, 46 (suppl. 1), 10.

Wood, S.M., Turner, P. \& Vere, D. (1980) Clinical phämacology and general patient care in two teaching ha्s pitals. Journal of the Roval Society of Medicine, 73, 399 